УДК 1(621.397.13:811)

DOI 10.35423/2078-8142.2019.5-6.05

С. В. Гулевський, аспірант кафедри теоретичної і практичної філософії імені професора Й. Б. Шада, Харківський національний університет імені В. Н. Каразіна, м. Харків, Украӥна e-mail:sgulevskyy@gmail.com ORCID: https://orcid.org/0000-0002-9819-7432

\title{
ФІЛОСОФСЬКИЙ АНАЛІЗ ТЕЛЕІНДУСТРІЇ: ВІД ДИСКУРСУ ДОМІНАНТНИХ СТРУКТУР ДО ДОМІНУВАННЯ ДИСКУРСУ
}

Статтю присвячено розгляду телеіндустрії під філософським кутом зору. Зокрема, здійснено аналіз критичних теорій щзоо економічних основ телеіндустрії, їі функиіонування як медіа та особливості означування у соціокультурному просторі. Розглянуто концепиіі масової культури Макса Горкгаймера і Теодора Адорно, дослідження інструментального характеру мас-медіа Гербертом Маркузе, суспільства спектаклю Гі Дебора, телематичного екрану Жана Бодріяра, неотрайбалізму Мішеля Маффесолі. Телеіндустрія постає як один з найбільш характерних проявів масової культури, а з іншого боку - як центральний елемент сучасної культурної індустрії. Розглянуто телесеріали як один з найбільш впливових елементів телеіндустрії, який здійснює вагомий вилив на формування цинностей та світогляду сучасної людини. Свого часу телебачення швидко набуло соиіальної домінантності і частково витіснило інщі види впливу масової культури на людину. Телебачення дедалі більшою мірою адаптується до новітніх засобів масової комунікаиії, зокрема вторгається у иарину мережі Інтернет. Телеіндустрія формує не лише смаки, а й домінантний у суспільстві дискурс, через який непомітно і владно формує життєві принципи i стратегію поведінки споживача телевізійного «продукmy»).

Ключові слова: масова культура, телеіндустрія, сочіальна комунікаиія, дискурс, домінантність, телесеріал.

(C) Гулевський С. В., 2019 
Теоретично-філософські розвідки стосовно місця та ролі телебачення у культурному просторі не так вже й віддалені від нас у часі, тому діахронний зріз відповідних досліджень поступається різноманітності підходів синхронного принципу вивчення телебачення i, зокрема, телевізійного серіалу. Навряд чи можна говорити про певну традицію дослідження телебачення, тут швидше маємо ситуацію незавершеного дискурсу як невпинного взаємного обміну і взаємного впливу різних, підчас несумісних, в усякому разі, на перший погляд, теорій і концепцій. Водночас, такий стан чимало науковців вважають не тимчасовим, властивим лише початковому етапу досліджень, а типовим, притаманним як сучасній філософській думці, так і самому іiі предмету, у цьому конкретному випадку - телебачення [11; 12$]$.

У своєму дослідженні будемо фокусувати увагу на особливому способі функціонування телебачення - телеіндустрії, а не розглядати феномен телебачення в цілому. Телеіндустрія постає як спроба взяти глядача під свій контроль - не просто забезпечити його потреби як споживача, але, як сказали б раніше, «заволодіти його душею», тобто визначати весь його спосіб життя. Телеіндустрія формує не просто смаки, але непомітно і владно формує цінності, світогляд, життєві принципи і стратегію поведінки споживача телевізійного «продукту». Під впливом телебачення люди купують речі, обирають друзів, одружуються, обирають президентів і парламенти, піддаються ейфорії і паніці.

Це трапилося не одномоментно - сучасне суспільство тривалий час еволюціонувало у напрямі посилення зворотного зв'язку між особистістю і масовою культурою, цей зв'язок ставав дедалі інтенсивнішим, жорсткішим, багатолінійним [5; 9]. Телеіндустрія у певний момент сконцентрувала у собі найбільш розвинені форми впливу масової культури на особистість і нині лише частково ділить пальму першості такого впливу з мережею Інтернет. Насправді, телеіндустрія давно зайшла на територію Інтернету і нині опановує деякі його специфічні можливості: навряд чи колись телеіндустрія зможе поглинути Інтернет, однак вона значною мірою спрямовує нині те, як саме людина користується ним. Для нових поколінь телеіндустрія все ж поступається пріоритетом порівняно 3 привабливістю віртуального світу Інтернету, однак за рівнем про- 
фесійності, досконалості і організованості впливу Інтернет ще тривалий час не зможе наздогнати телеіндустрію.

Сучасну добу характеризують подеколи епохою постмодерну, інколи постіндустріальним суспільством, а коли й інформаційним суспільством або ж добою диджиталізації, хоча йдеться про той самий проміжок часу - починаючи з другої половини XX ст. до нашого часу. Оскільки телевізійний серіал веде свій початок 3 появи комунікаційної ери прямої трансляції, тому він невідривно пов'язаний із супутніми особливостями виробництва та відтворення матеріальних благ. Водночас, вважаємо недоцільним обмежуватися виробничим детермінізмом, бо він тільки створює можливості, так би мовити, технічні умови для реалізації тієї чи іншої варіації культури. Соціокультурне середовище виступає не просто доволі важливим фактором для існування, розвитку чи трансформації будь-якої інструментальної інновативної системи, а базовою умовою для самого іiі виникнення і існування. Тримаючи у фокусі телевізійний серіал як предмет дослідження, проаналізуємо критичні теорії щодо економічних основ телеіндустрії, iї функціонування як медіа та особливості означування у соціокультурному просторі.

Практично одночасно з появою телебачення, як інструменту масової медіакомунікації, представники Франкфуртської школи Теодор Адорно та Макс Горкгаймер запропонували термін «культурна індустрія», який позначав серійні процеси та стандартизовані продукти, що виробляються на радіостанціях, кіностудіях та в редакціях популярних газет і журналів. Німецькі мислителі доводили абсолютну технологічну подібність та повну економічну залежність монополій культурної індустрії та промислового виробництва, а відтак - їх уніфікованість. Важливо зазначити, що їх праця створювалася у добу панування односторонньої (аналогової) телевізійної та радіо трансляції.

На момент написання «Діалектики Просвітницва» [10], телевізійних серіалів ще не було, а телебачення демонструвало тільки несміливі спроби «прагнути до синтезу радіо і фільму» [10, с. 154]. Щоправда, існували радіо серіали, так звані мильні опери, які критикувалися франкфуртцями у загальному негативному ключі у такий спосіб, що «... драматична інтрига «мильних опер» на радіо перетворюється у підсумку на морально повчальний приклад по68

Institute of Philosophy of H. S. Skovoroda of NAS of Ukraine 
долання технічний складнощів, що долаються однаковим чином» [10, с. 152]. Вони зазначали їх циклічність, «зашкарублу інваріантність», похідні характеристики сюжетного змісту [10, с. 152]. Автори «Діалектики Просвітницва» не вважали, що медіа виробництво враховує побажання публіки (рекурс до бажань публіки). Вони пояснювали такий підхід вимогами технологічного процесу та економічним відбором, натякаючи на «змову» вищого менеджменту монополій у сфері культури з метою не виробляти нічого 3 того, що не відповідає їх уявленням про споживача. Слід відзначити, що, на думку Т. Адорно та М. Горкгаймер, вся продукція культурної індустрії/машинерії була націлена на відтворення на екрані саме реального життя, що сприяло пригнічуванню фантазію і думки глядача.

Проблеми розвинутої індустріальної цивілізації як західного типу культури, так і тоталітарно-деспотичної радянської системи розглянув інший представник франкфуртської школи - Герберт Маркузе. Ідеться про його найбільш відому працю «Одновимірна людина. Дослідження ідеології розвинутого індустріального суспільства» [7]. У цій праці висвітлюється інструментальний характер мас-медіа, насамперед як засобів масової інформації, у формуванні стандартизованого «одномірного мислення і поведінки» [7, с. 16]. У цьому контексті телебачення постає дуже ефективним засобом реалізації тотального економіко-технологічного контролю та маніпуляції свідомістю індивідів з боку істеблішменту, як позначив Г. Маркузе, або незначної частини суспільства, що володіє виробничим апаратом. За радіо і телебаченням закріплюються дві ідеологічні функції: «пом'якшення від отупіння» після непотрібної роботи і вирівнювання класових відмінностей між босом та робітником, оскільки всі дивляться один і той самий телепродукт чи слухають радіотрансляцію [7, с. 10-11]. Уся інформаційна індустрія нав'язує певні моделі інтелектуальних, емоційних реакцій, які перетворюються на суспільний і приватний способи життя. При цьому висока культура i мистецтво відхиляються, за висловом Г. Маркузе, а медіа створюють мішанину з того ж таки мистецтва, політики, релігії та реклами, яку приводять «до спільного знаменника - товарної форми» [7, с. 74]. Виразну приземленість, що стирає відмінності між художньою та соціальною реальностями, 
впроваджує медіа індустрія під тиском технологічного суспільства, тому мистецтва стають «гвинтиками культурної машини» [7, с. 83].

Аналіз ролі радіо та телебачення на радянському просторі у книжці Г. Маркузе відсутній, що не дивно. Проте, на власному досвіді, можемо твердити про абсолютну заідеологізованість та пропагандистський характер медіа продуктів у радянські часи. Це вписується у загальну ідею тотального координування та маніпуляцій індустріальної доби, за тим винятком, що ніякої «Держави Благополуччя» на цій території не існувало, а вся ідеологія трималася на тому, що державу оточують вороги.

Найкритичніші ідеї щодо суспільства розвинутої економіки викладені у творі Гі Дебора «Суспільство спектаклю» [4], де існуючий порядок речей і стосунків між людьми характеризується за допомогою концепту «спектаклю», який було створено під впливом марксистської критики хибної свідомості. Перш за все, поява «спектаклю» - це не просто рандомний епізод історії європейської цивілізації, ініційований неймовірним технічним удосконаленням медійних засобів. На думку автора цього концепту, він укорінюється у найдавнішій спеціалізації влади «говорити від імені інших» [4, с. 29]. «Спектакль» заміщає реальність у будь-якому ієрархічному суспільстві, тож не буде хибою вважати «спектакль» Дебора знаком (оскільки замінник) владного істеблішменту. В умовах держави розвинутої економіки суспільство спектаклю - це «необмежене правління ринкової економіки, що досягла статусу нікому не підзвітного суверенітету, і системою нових технологій управління» $[4$, с. 120$]$.

У Гі Дебора «спектакль» - це псевдосвіт, псевдочас, псевдожиття i, звісно, псевдорай. Дебор називає спектаклем хибну ідеологію, яка уніфікує життєвий світ через видовище, через акцентуацію одного з видів перцепції - бачення. У середовищі спектаклю справжнє життя і справжні зірки - це товари, які самі по собі теж не надто реалістичні, бо, на думку Г. Дебора, являють собою ілюзії, а знаменитості тільки репрезентують різноманітні товари споживання і не мають істинного життя. На верхівці цього «айсберга» стоять медіа - найбільш яскраве втілення ситуації «спектаклю», які забезпечують його функціонування та самовідтворення. Слід зазначити, що медіа, а також їх частина телебачення, не були виок70

Institute of Philosophy of H. S. Skovoroda of NAS of Ukraine 
ремлені Дебором в якийсь особливий блок міркувань, проте їх відсутність як окремого об'єкта критики вказує на їх тотальний характер у суспільстві спектаклю, основу його діяльності, хоча й не ставить знак рівності між ними. У своїх «Коментарях до «Суспільства спектаклю» французький теоретик підкреслив інструментальний характер мас-медіа, застерігши, що не варто плутати «спектакль» та засоби масової інформації, які начебто, як новий суспільний сервіс, професійно керують «комунікаційним достатком» та інколи породжують окремі, часткові спектаклі: «спектакльполітика, спектакль-юстиція, спектакль-медицина» [4, с. 122]. За таких умов, спектакль можна було б представити як побічний ефект мас-медіа, натомість реальний суспільний «спектакль» - це централізуюча, деспотична влада «власників світу» [4, с. 122]. Ідеї Гі Дебора значно вплинули на наступні покоління теоретиків культури та мас-медіа і важливі для розуміння витоків теоретичних розмислів багатьох постмодерністів, зокрема Жана Бодрійяра.

Як своєрідна екстраполяція творчого доробку марксистів франкфуртської школи і Гі Дебора була написана одна 3 праць постмодерніста Жана Бодрійяра, присвячена аналізу кінця зв'язного та осмисленого соціального простору [1]. Саме до такої розв'язки призвело функціонування «одновимірного» суспільства, «одновимірної» людини, суспільства спектаклю та культіндустрії разом із маніпулятивними медіа, коли формується особливий стан «маси», на противагу народу/спільноті. «У тіні мовчазної більшості» французький філософ також дав критичну характеристику населення сучасних країн, де будь-яка репрезентація, смисл, економіка, інформація та інше просто зникає, бо на його думку, маса володіє такою характеристикою, як імплозивність, та не може бути осягнута «будь-якою практикою і будь-якою теорією» [1, с. 7]. Зазначаючи, що маса жадає видовищ, Ж. Бодрійяр дуже скептично оцінює роль телебачення у намаганнях влади структурувати аморфну масу населення через певну циркуляцію інформації, з чим неможливо не погодитись. Усе навпаки - телебачення тільки погіршує ситуацію, бо автоматично примножує масу, яка категорично «нечутлива до змісту самої інформації» [1, с. 32].

Майже діаметральний переворот у сприйнятті суб'єкта/об'єкта комунікації відбувається за умови комунікації че- 
рез екран машини, яка погіршує всю чуттєвість людини. Ж. Бодрійяр, здається, гіперболізує, коли стверджує, що «всі наші машини - це екрани, внутрішня активність людей стала інтерактивністю екранів» [2, с. 80]. Але як не погодитися, що така комунікація годиться для абсолютно абстрактної форми спілкування. Телематичний екран - один із видів у низці машинних екранів, який створює особливий просторовий вимір, відмінний від людського, де неможливо розрізнення між суб'єктом і об'єктом, між зовнішнім та внутрішнім. У своєму есеї «Ксерокс і безкінечність» Ж. Бодрійяр пропонує концепт Людини Телематичної, як символу функціональної зчепленності людського тіла та апаратної машини штучного розуму і стверджує, що віднині не існує «ні дії, ні події, які б не заломлювалися в технічному зображенні або на екрані, ні однієї дії, яка б не відчувала бажання бути сфотографованою, зафільмованою на плівку, записаною на магнітофон, яка б не прагнула злитися з цією пам'яттю і здобути всередині неї невичерпну здатність до відтворення» [2, с. 84]. Тож телебачення для Людини Телематичної, разом з іншими засобами апаратної комунікації, відіграє роль своєрідного протеза інтелектуально-вольової діяльності.

Щоправда, мас-медіа самі сприяли тому, що простір соціального перетворився на суцільну симуляцію, бо там, де повинні бути повідомлення, ідея, істина «панує медіум, ідол і симулякр» [1, с. 43]. Комунікація, телебачення як іiі частина, спричинили «нейтралізацію смислу», анулювавши зв'язок означника з означуваним, спустошивши культурні знаки. Політика - ігри та спектакль, економіка - потерпає від руйнівного впливу маси, кіномистецтво - все пішло у сферу уявного, бо справжній медіум - це маca, яка «медіум набагато більше потужний, ніж всі засоби масової інформації разом узяті» [1, с. 52].

Не маса, але й не організоване суспільство, де панує індивідуалізм та людина є творцем історії, а сучасний «неотрайбалізм» (поняття, запропоноване Мішелем Маффесолі) характеризує кінець часу раціональності, модерну, що може свідчити не лише про завершення однієї певної епохи, а й позначати початок нової. Саме масовізація сприяла актуалізації спонтанного «спільного буття», де випадковим чином формуються малі спільноти. Мішель Маффесолі досить оптимістично оцінює ситуацію, коли органічна, природна 72

Institute of Philosophy of H. S. Skovoroda of NAS of Ukraine 
душа людини, яка апріорі схильна до чуттєвості, тілесності, спільних переживань радощі та болю, ніби звільняється від тиску «іудео-християнства» та буржуазності та, на його думку, «знов повертається до життя» [8, с. 29]. Характеристики нової форми солідарності, насправді, просто приховано використовують найдавніші форми усуспільнення, які грунтуються на спільних емоційних переживаннях. М. Маффесолі пропонує не драматизувати сучасну соціальну ситуацію і через вивчення таких категорій, як невизначена громада, безликий натовп і трайбалізм спробувати угледіти зародки нового відродження цивілізації. Він стоїть на позиції, що хоч би як це виглядало фантастично, але «можливо, необхідно показати (як це зробили деякі письменники-романісти), що особистість більше не є основою субстанціалізму» [8, с. 44].

Отже, дивлячись «відкритими очима» на всі складнощі сучасності постмодерну, Мішель Маффесолі просто означує цей період історії як емпатичний, на відміну від абстрактнораціонального, і закликає досліджувати наше співвідношення один 3 одним у методологічному полі проксеміки. Для його характеристики він використовує поняття «естетична парадигма» як дещо спільно пережите та відчуте, відсутність диференціації та розчинення у колективному суб'єкті або «неотрайбалізм» [8, с. 45]. До речі, низка телесеріалів, а саме: «Друзі» (Friends) каналу NBC, «Універ» каналу ТНТ та «Спільнота» (Community), що перші 5 ceзонів також випускав канал NBC та фінальний 6-й сезон Yahho!Screen яскраво демонструють, наскільки мистецтво може миттєво відображати реалії соціального життя, значно випереджаючи наукових теоретиків.

Основою новітньої соціальності є нестабільні, відкриті емоційні спільноти. М. Маффесолі вважає, що головна відмінність спільноти від суспільства полягає у тому, що спільнота не надто переймається своїм майбутнім, а здебільшого теперішнім, в якому концентрована вся іiі енергія. Цю енергію спільнота витрачає на самостворення та самовідтворення через такий тип взаємин, що «по своїй суті не має завершеної форми, тобто кінцевої мети; навпаки, він гарантовано повторюється», практично через обряд [8, с. 53]. Це настільки очевидно, що автору «Часу племен» доводиться говорити про релігійність, проте релігійність у контексті 
неотрайбалізму набуває архаїчних ознак і мислиться як емоційне об’єднання, «чуттєва туманність», що повинна символізувати сучасну соціальність. Такого типу релігійність, як зауважує М. Маффесолі, «вільно співіснує 3 технологічними засобами та підкріплюється ними» [8, с. 127]. Відзначимо, що вже у цьому пункті постає питання: а чи не перемістився змістовний акцент 3 релігійності на технологічні засоби? Видається, що саме технологічні засоби стають центром, генератором соціальності штибу «чуттєвої туманності» та конструюють соціальні зв'язки і спільноти - новітні трайби (племена).

Проте телебачення, навіть у контексті «глобального села» (Маффесолі наводить приклад з опорою на концепт М. Маклюена), $\epsilon$ тільки мобілізаційним чинником колективних емоцій для членів спільнот, хоча й у планетарному масштабі, підтримуючи різноманітні волонтерські рухи, громадські об’єднання тощо. Оскільки Мішель Маффесолі всіляко підкреслює важливість колективних, спільних емоцій, то трансляція та агрегація цих емоцій здійснюється завдяки мас-медіа, головним серед яких в його праці видається телебачення. Французький мислитель постулює, що «єдиною причиною існування неотрайбалізму є спільне переживання колективного теперішнього часу» [8, с. 122], що справді може забезпечити телевізійна трансляція, зокрема одночасний перегляд нових епізодів серіалу. Водночас, Мішель Маффесолі відзначає, що слід провести належне дослідження телекомунікаційних мереж, щоб підтвердити майбутні перспективи новітніх трайбів, що існують у мегаполісах на основі спільних почуттів, досвіду та переживань.

Отже, телебачення у ролі комунікаційного чинника, що діє не тільки, а на разі і не стільки у звичному форматі аналогового транслювання, а й через цифрові мережі, у праці М. Маффесолі постає поєднальним елементом розрізнених груп і створює згуртовану масу. Маса у М. Маффесолі або «неотрайб» має позитивні конотації, на відміну від маси Ж. Бодрійяра та деяких інших теоретиків. Інтернет мережа тільки посилює цю здатність усуспільнення завдяки інтерактивності мереж, оскільки у такий спосіб можна створювати «комунікаційну матрицю, в якій групи з різними цілями з'являються, розвиваються і зникають» [8, с. 201]. Такий погляд відкриває новий простір для осмислення феномена телесеріалу у 74

Institute of Philosophy of H. S. Skovoroda of NAS of Ukraine 
контексті формування спільнот як з погляду проксеміки, на чому наголошує М. Маффесолі, так і з позиції обрядовості.

Український дослідник М.Бойченко звертає увагу на владний характер дискурсивних практик, розвиваючи ідеї Мішеля Фуко: «Дискурсивні практики - специфічні самовідтворювані форми мовленнєвої комунікації... історія є послідовністю і часовою сумісністю дискурсивних формацій, а соціальний простір визначається сукупністю усіх наявних у даному суспільстві дискурсивних формацій. Ці формації знаходяться між собою у складних стосунках, які не можна охарактеризувати лише як диференціацію, ієрархію, вибіркову спорідненість, автономію чи взаємне проникнення - вочевидь, різною мірою наявні водночас усі ці види стосунків між дискурсивними формаціями. Тією мірою, якою дискурсивні практики регулюють поведінку людей, можна говорити про їхню владу» [3, с. 24]. Дослідник говорить також про певні обмеження влади дискурсивних практик: технічні, смислові, соціальні та антропологічні. Так, владу дискурсивних практик обмежує необхідність використання другої знакової системи, тих смислів, які вона може форматувати, визначених соціальних носіїв і коридор сприйняття реальності, доступний людині [3, с. 24-25]. Однак, якщо звернемося до телебачення, здається, що воно прагне оминути ці обмеження: дискурс доповнюється емоціями, зоровими образами, які мають символічну невичерпність, його цільова аудиторія, хоча й обмежена, однак тяжіє до постійного розширення. I навіть антропологічні рамки телебачення прагне якщо не подолати, то суттєво розсунути завдяки створенню віртуального простору, в якому легко долаються географічні та часові кордони, а людські можливості виявляються набагато більш пластичними, ніж це доступно пересічній людині. Телебачення творить новий магічний світ, а тому приваблює і зваблює глядача поцейбічним раєм, доступним і зрозумілим.

Таким чином, аналіз телеіндустрії загострює розуміння того, що феномен телебачення не можна розглядати як маніпулятивну практику, в якій майстри режисури, сценаристи, продюсери та інші творці телепродукту є ляльководами слухняної маси. Усі учасники функціонування телеіндустрії $є$ учасниками складного комунікативного процесу, в якому суб'єктом постає сама телеіндустрія як дискурс. Унаочнюють і значною мірою моделюють цей дискурс 
телесеріали: вони переконливо засвідчують, як «закони жанру» диктують поведінку акторів, і не лише на екрані, але усіх соціальних акторів, задіяних у виробництво і споживання телесеріалів. Телебачення створює нову спільну атмосферу, яка насичена емоціями - саме через емоції транслюються основні смисли і цінності, завдяки емоціям дискурс телебачення стає домінуючим і витісняє інші дискурси.

\section{ЛITEPATУРA}

1. Бодрийяр Ж. В тени молчаливого большинства, или конец социального / пер. с франц. Н. В. Суслова. Екатеринбург : Изд-во Уральского университета, 2000. $96 \mathrm{c}$.

2. Бодрийяр Ж. Прозрачность зла / пер. с франц. Л. Любарской и Е. Марковской. М. : Добросвет, 2009. 387 с.

3. Бойченко М. Влада дискурсивних практик. Дискурс в умовах мінливості сочіокультурного простору: матеріали Всеукраїнської науковопрактичної конференції з міжнародною участю до 95-річчя Мелітопольського державного педагогічного університету імені Богдана Хмельницького (20-21 квітня 2018 р.) / заг. ред. Р. Олексенка. Мелітополь : Видавництво МДПУ імені Богдана Хмельницького, 2018. С. 24-25.

4. Дебор Г. Общество спектакля / пер. с фр. С. Офертаса и М. Якубович. М. : Логос, 1999. 224 с.

5. Дзюба Д. Міфотворчість постмодерністського телепростору України. Украӥнське мистеитвознавство: матеріали, дослідження, рецензії: зб. наук. пр. 2009. Вип. 9. С. 259-263.

6. Маклюэн М. Понимание Медиа: Внешние расширения человека / пер. с англ. В. Г. Николаева. М. : Жуковский: Канон-пресс-Ц, Кучково поле, 2003. 464 c.

7. Маркузе Г. Одномерный человек: Исследование идеологии развитого индустриального общества / пер. с нем. M. : Refl-book, 1994. 342 c.

8. Маффесолі М. Час племен. Занепад індивідуалізму у постмодерному суспільстві / пер. 3 фр. В. Плющ. К. : ВД «Києво-Могилянська академія», 2018. 264 с.

9. Хворостина О. В. Трансмедійність контенту. Кросмедіа: контент, технології, перспективи: колективна монографія / заг. ред. В. Е. Шевченко. Київ, 2017. С. 130-138.

10. Хоркхаймер М., Адорно Т. Диалектика просвещения: Философские фрагменты / пер. с нем.. М.-СПб. : Медиум. Ювента, 1997. 311 с. 
11. Collins J. Transmediaphilia, World Building, and Pleasures of the Personal Digital Archive. World Building. Transmedia, Fans, Industries / ed. by M. Boni. Amsterdam, 2017. P. 362-376.

12. Taylor P., Harris J. Critical Theories of Mass Media : Then and Now. Buckingem : Open University Press, 2008. 233 p.

\section{REFERENCES}

Baudrillard, J. (2000). In the shadow of the silent majority, or the end of the social. Ekatery`nburg: Y`zd-vo Ural`skogo unyversyteta. 96 p. [In Russian].

Baudrillard, J. (2009). The transparency of evil. Moscow : Dobrosvet. 387 p. [In Russian].

Bojchenko, M. (2018). The power of discursive practices. Discourse in the context of changing socio-cultural space: materials of the All-Ukrainian Scientific-Practical Conference with International Participation to the 95th Anniversary of Bogdan Khmelnytskyi Melitopol State Pedagogical University (April 20-21). R. Oleksenko (Ed.). Melitopol: Vzdavnycztvo MDPU imeni Bogdana Xmelnyczkogo. 24-25. [In Ukrainian].

Debor, G. (1999). The society of the Spectacle. Moscow : Logos. 224 p. [In Russian].

Dzyuba, D. (2009). Mythmaking of postmodern television space of Ukraine. Ukrainian Art Studies: Materials, Research, Reviews: Collected Science Papers. Kyiv. Vol. 9. 259-263. [In Ukrainian].

McLuhan, M. (2003) Understanding Media: The Extensions of Man. Moscow : Zhukovskyj: Kanon-press-Cz, Kuchkovo pole. 464 p. [In Russian].

Marcuse, G. (1994). One-dimensional Man: Studies in the Ideology of Advanced Industrial Society. Moscow : Refl-book. 342 p. [In Russian].

Maffesoli, M. (2018). Tribal time. The decline of individualism in a postmodern society. Kiev : VD “Kyyevo-Mogylyans kka akademiya”. 264 p. [In Ukrainian].

Xvorosty`na, O. V. (2017). Transmedia content. Crossmedia: Content, Technology, Perspectives: A Collective Monograph. V. E. Shevchenko (Ed.). Kyiv. 130-138. [In Ukrainian].

Horkheimer, M., Adorno, T. (1997) Dialectics of Enlightenment: Philosophical Fragments. Moscow - St. Petersburg : Medy`um. Yuventa. 311 p. [In Russian]. 
Collins, J. (2017). Transmediaphilia, World Building, and Pleasures of the Personal Digital Archive. World Building. Transmedia, Fans, Industries. M. Boni (Ed.). Amsterdam. 362-376.

Taylor, P., Harris, J. (2008). Critical Theories of Mass Media : Then and Now. Buckingem : Open University Press, 2008. 262 p.+ xiii.

\title{
Sergey Gulevsky
}

Post-Graduate Student of the Department of Theoretical and Practical Philosophy named by J. B. Schad, V. N. Karazin Kharkiv National University; Kharkiv, Ukraine; e-mail: sgulevskyy@gmail.com; ORCID: https://orcid.org/ 0000-0002-9819-7432

\section{Philosophical analysis of the television industry: from the discourse of domi- nant structures to the dominance of discourse}

\begin{abstract}
s
The article deals with the view of the television industry from a philosophical perspective. In particular, the analysis of critical theories concerning the economic foundations of the television industry, its functioning as a media, and peculiarities of definition in the socio-cultural space are carried out. There are considered the concepts of mass culture of Max Horkheimer and Theodore Adorno, the study of the instrumental character of the mass media by Herbert Marcuse, the concepts of the society of the play of Guy Deborah, the telematic screen of Jean Baudrillard, the neo-tribalism of Michel Muffesoli. The television industry appears as one of the most characteristic manifestations of mass culture and, on the other hand, as a central element of the modern cultural industry. The socio-cultural environment is not just a very important factor for the existence, development or transformation of any instrumental innovative system, but a basic condition for its emergence and existence. The entire information industry imposes certain patterns of intellectual, emotional responses that are transformed into public and private lifestyles. The media is the most vivid embodiment of the situation of "spectacle", which ensure its functioning and reproduction. There are considered television series as one of the most influential elements of the television industry, which has a significant impact on the formation of values and worldview of modern human. At one time, television quickly became socially dominant and partially supplanted other types of influence of mass culture on humans. Television is increasingly adapting to
\end{abstract}


the latest mass media, in particular invading the realm of the Internet. The television industry forms not just tastes, but a dominant in society discourse through which imperceptibly and powerfully forms the life principles and strategy of behavior for the consumers of the television "product". All participants in the functioning of the television industry are participants in a complex communication process in which the television industry as a discourse becomes the real subject. Television series illustrated and largely modeled this discourse: they show convincingly how the "laws of genre" dictate the behavior of actors, and not only on screen, but of all social actors involved in the production and consumption of television series. Television creates a new shared atmosphere that is saturated with emotions - the basic meanings and values are transmitted through emotions, thanks to emotions the discourse of television becomes dominant and displaces other discourses.

Keywords: mass culture, television industry, social communication, discourse, dominance, television series. 